medRxiv preprint doi: https://doi.org/10.1101/2021.03.09.21252944; this version posted March 12, 2021. The copyright holder for this preprint (which was not certified by peer review) is the author/funder, who has granted medRxiv a license to display the preprint in perpetuity.

\title{
A phase 2 study of the inhaled pan-JAK inhibitor TD-0903 in severe COVID-19: Part 1
}

Dave Singh, ${ }^{1}$ Maxim Bogus, ${ }^{2}$ Valentyn Moskalenko, ${ }^{3}$ Robert Lord, ${ }^{4}$ Edmund J. Moran,,${ }^{5}$ Glenn D.

Crater, ${ }^{5 *}$ David L. Bourdet, ${ }^{5}$ Nathan D. Pfeifer, ${ }^{5}$ Jacky Woo, ${ }^{5}$ Elad Kaufman, ${ }^{5}$ David A. Lombardi, ${ }^{5}$ Emily

Y. Weng, ${ }^{5}$ Tuan Nguyen, ${ }^{5}$ Ashley Woodcock, ${ }^{4}$ Brett Haumann, ${ }^{6}$ Rajeev Saggar ${ }^{5}$

*Former employee of Theravance Biopharma US, Inc.

${ }^{1}$ Medicines Evaluation Unit

University of Manchester

Manchester University NHS Foundations Trust

Manchester, UK

${ }^{2}$ Arensia Exploratory Medicine SRL

Timofei Mo $\square$ neaga Republican Clinical Hospital

Chi $\square$ inău, Moldova

${ }^{3}$ Arensia Exploratory Medicine, LLC

Kyiv City Clinical Hospital \#12, Kyiv, Ukraine

Oleksandrivska Kyiv City Clinical Hospital, Kyiv, Ukraine

Brovary Multidisciplinary Clinical Hospital, Brovary, Ukraine

${ }^{4}$ University of Manchester

Manchester University NHS Foundations Trust

Manchester, UK 
medRxiv preprint doi: https://doi.org/10.1101/2021.03.09.21252944; this version posted March 12, 2021. The copyright holder for this preprint (which was not certified by peer review) is the author/funder, who has granted medRxiv a license to display the preprint in perpetuity.

All rights reserved. No reuse allowed without permission.

${ }^{5}$ Theravance Biopharma US, Inc.

South San Francisco, CA, USA

${ }^{6}$ Theravance Biopharma UK Limited

London, UK

\section{Corresponding author:}

Rajeev Saggar

Theravance Biopharma US, Inc.

901 Gateway Boulevard

South San Francisco, CA 94080, USA

rsaggar@theravance.com 
medRxiv preprint doi: https://doi.org/10.1101/2021.03.09.21252944; this version posted March 12, 2021. The copyright holder for this preprint (which was not certified by peer review) is the author/funder, who has granted medRxiv a license to display the preprint in perpetuity.

All rights reserved. No reuse allowed without permission.

\begin{abstract}
Background: Lung-targeted anti-inflammatory therapy could potentially improve outcomes in patients with COVID-19. The novel inhaled pan-Janus kinase (JAK) inhibitor TD-0903 was designed to optimise delivery to the lungs while limiting systemic exposure. Here, we report results from the completed Part 1 of a 2-part phase 2 trial (NCT04402866) in hospitalised patients with severe COVID-19.

Methods: Part 1 explored 3 doses of TD-0903 (1,3, and $10 \mathrm{mg}$ once-daily for 7 days) and placebo in a randomised, double-blind, ascending-dose study. Each dose cohort comprised 8 hospitalized patients (6:2 TD-0903:placebo) with PCR-confirmed COVID-19 requiring supplemental oxygen and receiving background standard-of-care therapy. Key objectives included safety and tolerability, pharmacokinetics, and oxygen saturation/fraction of inspired oxygen ratio; clinical outcomes were also explored. Data were summarised as descriptive statistics.

Results: Twenty-five patients were randomised to receive TD-0903 $1 \mathrm{mg}(\mathrm{n}=6), 3 \mathrm{mg}(\mathrm{n}=7), 10 \mathrm{mg}(\mathrm{n}$ $=6)$, or placebo $(n=6)$. Almost all patients $(92 \%)$ received background dexamethasone; $3(12 \%)$ received remdesivir. TD-0903 was generally well tolerated with no drug-related serious adverse events. Low plasma concentrations of TD-0903 were observed at all doses. Clinically favourable numerical trends in patients receiving TD-0903 vs placebo included improved 8-point clinical status, shortened hospitalisation, improved oxygenation, and fewer deaths.
\end{abstract}

Conclusions: In Part 1 of this phase 2 trial, the novel inhaled JAK inhibitor TD-0903 showed potential for treatment of patients with severe COVID-19. TD-0903 $3 \mathrm{mg}$ is being evaluated in Part 2 of the randomised, double-blind, parallel-group trial in 198 hospitalized patients with COVID-19. 
medRxiv preprint doi: https://doi.org/10.1101/2021.03.09.21252944; this version posted March 12, 2021. The copyright holder for this preprint (which was not certified by peer review) is the author/funder, who has granted medRxiv a license to display the preprint in perpetuity.

All rights reserved. No reuse allowed without permission.

Severe coronavirus disease 2019 (COVID-19) is characterised by pneumonia with high levels of systemic inflammation, referred to as a "cytokine storm.”[1-3] Dexamethasone treatment decreases mortality in patients with COVID-19 who are receiving respiratory support and is now considered standard of care for patients with severe COVID-19.[4, 5] The orally administered Janus kinase (JAK)-1/2 inhibitor baricitinib in combination with the antiviral remdesivir has also shown clinical efficacy in patients with severe COVID-19.[6] JAK inhibition blocks cytokine signalling through signal transducer and activator of transcription (STAT) pathways, offering broad immunomodulation.[7] As pulmonary inflammation and associated diffuse alveolar damage drive COVID-19 morbidity and mortality,[3] lung-targeted antiinflammatory therapy could potentially improve outcomes. The novel inhaled pan-JAK inhibitor TD-0903 was specifically designed to target all JAK isoforms (JAK1, JAK2, JAK3, TYK2) and optimise delivery to the lungs while limiting systemic exposure. Here, we report results from the completed Part 1 of a 2part phase 2 trial (NCT04402866) in hospitalised patients with severe COVID-19.

This phase 2 study was designed with separate data reporting for Parts 1 and 2. Part 1 was a randomised, double-blind, placebo-controlled, multiple-ascending-dose trial conducted in the UK, Moldova, and Ukraine. The study protocol and related documents were approved by independent ethics committees at each site. The study was conducted in accordance with the principles of Good Clinical Practice and the Declaration of Helsinki. Patients provided informed consent. Patients 18 to 80 years of age with PCRconfirmed symptomatic COVID-19 (symptoms for 3-14 days) who were hospitalised and required supplemental oxygen to maintain saturation $>90 \%$ were eligible. Patients receiving JAK inhibitors or anti-interleukin-6 therapy were excluded. Patients were sequentially enrolled in 3 ascending-dose cohorts $(\mathrm{n}=8 ; 6$ active and 2 placebo per cohort) and received once-daily TD-0903 $1 \mathrm{mg}$ (Day 1 loading dose 2 $\mathrm{mg}$ ), $3 \mathrm{mg}$ (Day 1 loading dose $6 \mathrm{mg}$ ), or $10 \mathrm{mg}$ (no loading dose) or matched placebo via inhalation (Aerogen Solo + Ultra nebuliser system, Galway, Ireland) for up to 7 days, with follow-up through Day 28. Loading doses were administered on Day 1 for the 2 lowest maintenance dose levels ( 1 and $3 \mathrm{mg}$ ) to rapidly achieve pseudo-steady state in the lung. 
medRxiv preprint doi: https://doi.org/10.1101/2021.03.09.21252944; this version posted March 12, 2021. The copyright holder for this preprint (which was not certified by peer review) is the author/funder, who has granted medRxiv a license to display the preprint in perpetuity.

All rights reserved. No reuse allowed without permission.

Peripheral oxygen saturation ( $\mathrm{SaO} 2)$ was collected via pulse oximetry, and fraction of inspired oxygen (FiO2), vital signs, adverse events (AEs), and clinical status using an 8-point ordinal scale (OS)[8] were recorded daily though Day 7 and on Days 14, 21, and 28 and/or at hospital discharge. Physical examination, blood collection, and serum chemistry evaluations occurred on Days 1 and 7; patient carerelated laboratory evaluations through Day 28 were also included. Key safety outcomes were change from baseline in vital signs and clinical laboratory results, and incidence and severity of treatment-emergent AEs (TEAEs; coded per Medical Dictionary for Regulatory Activities v23.1); key pharmacokinetic (PK) endpoints were plasma PK parameters on Days 1 and 7, and the key pharmacodynamic outcome was change from baseline $\mathrm{SaO} 2 / \mathrm{FiO} 2$ ratio. Other clinical outcomes were considered exploratory.

A sample size of 8 patients per cohort (6 active, 2 placebo) was deemed appropriate to assess TD--0903 safety and tolerability during dose escalation. Safety, $\mathrm{SaO} 2 / \mathrm{FiO} 2$ ratio, and efficacy data were summarised as descriptive statistics using SAS version 9.4 (SAS Institute, Cary, NC, USA).

Twenty-five patients enrolled and were randomised to receive TD-0903 $1 \mathrm{mg}(\mathrm{n}=6), 3 \mathrm{mg}(\mathrm{n}=7), 10 \mathrm{mg}$ $(n=6)$, or placebo $(n=6)$. One patient receiving TD-0903 $3 \mathrm{mg}$ was discontinued due to a negative SARS-CoV-2 PCR screening test returned after randomisation; per protocol, this subject was replaced. Baseline data, concomitant medications, TEAEs, and clinical outcomes are summarised in the Table. Almost all patients (92\%) received dexamethasone; 3 (12\%) received remdesivir. The majority of TEAEs were mild to moderate and resolved by end of study, with no apparent dose relationship. Serious TEAEs occurred in 5 patients through Day 28, including COVID-19 progression in 1 placebo-treated patient; acute respiratory distress syndrome (ARDS) and fatal multiple organ dysfunction syndrome (MODS) in 1 placebo-treated patient; ARDS and fatal cardiac arrest in 1 placebo-treated patient; acute respiratory failure, ventricular fibrillation, and fatal MODS in 1 patient receiving TD-0903 $1 \mathrm{mg}$; and ischaemic stroke in 1 patient receiving TD--0903 $3 \mathrm{mg}$. No serious TEAEs were considered related to study 
medRxiv preprint doi: https://doi.org/10.1101/2021.03.09.21252944; this version posted March 12, 2021. The copyright holder for this preprint (which was not certified by peer review) is the author/funder, who has granted medRxiv a license to display the preprint in perpetuity.

All rights reserved. No reuse allowed without permission.

treatment by the investigator. One patient receiving TD-0903 $10 \mathrm{mg}$ discontinued treatment on Day 4 due to an elevation in alanine aminotransferase (ALT) that resolved without consequence. No other changes in vital signs or laboratory safety measures, including creatinine and haematologic parameters, were attributed to treatment. The mean steady state maximal plasma concentration $\left(\mathrm{C}_{\max }\right)$ of TD-0903 at the highest dose was $19.0 \mathrm{ng} / \mathrm{mL}$, well below levels predicted to produce systemic JAK inhibition.

At baseline, all patients received supplemental oxygen via nasal prongs or mask (OS 5). Within the 7-day treatment period, $3(50 \%)$ placebo-treated patients progressed to invasive mechanical ventilation (OS 7). In contrast, no patient receiving TD-0903 had a decline in clinical status. This pattern was maintained throughout the 28-day study period for patients receiving TD-0903 3 or $10 \mathrm{mg}$. One patient treated with TD-0903 $1 \mathrm{mg}$ and 2 placebo-treated patients died (OS 8) before Day 28 (Day 23 for patient treated with TD-0903 $1 \mathrm{mg}$ and Days 11 and 14 for placebo-treated patients); no patients treated with TD-0903 3 or 10 mg died during the 28-day study period. Improved $\mathrm{SaO} 2 / \mathrm{FiO} 2$ ratio from baseline to Day 7 was observed in patients receiving TD-0903 vs placebo. The proportion of patients alive and respiratory failure-free at Day 28 was higher and mean time to hospital discharge was shorter in patients treated with TD-0903 vs placebo (Table).

This is the first clinical trial to date of delivery of a JAK inhibitor directly to the lung via inhalation in patients with COVID-19. Once-daily inhaled TD-0903 treatment for 7 days was generally well tolerated in patients with severe COVID-19. There were trends toward improvement in $\mathrm{SaO} 2 / \mathrm{FiO} 2$ ratio, proportion of patients alive and respiratory failure-free at Day 28, and mean time to hospital discharge in patients treated with TD-0903 vs placebo. Overall mortality was 33\% in placebo-treated patients vs 5\% in patients treated with any dose of TD-0903. The small sample size of this early phase clinical trial limited evaluation of clinical efficacy through between-group comparisons and formal control for potential confounders. Nevertheless, the low mortality and pattern of earlier clinical recovery with TD-0903 vs placebo treatment suggests promise for the strategy of targeting cytokine-driven inflammation in the 
medRxiv preprint doi: https://doi.org/10.1101/2021.03.09.21252944; this version posted March 12, 2021. The copyright holder for this preprint (which was not certified by peer review) is the author/funder, who has granted medRxiv a license to display the preprint in perpetuity.

All rights reserved. No reuse allowed without permission.

lungs of patients with severe COVID-19 through pan-JAK inhibition. Notably, JAK inhibition may have additive anti-inflammatory effects when used in combination with corticosteroid treatment[9]—which almost all patients in the study received - and thus using these treatments in combination may be complementary for the treatment of patients with COVID-19.

Based on the totality of evidence, inhaled TD-0903 $3 \mathrm{mg}$ was advanced for further evaluation in Part 2 of this study, a larger $(\mathrm{N} \approx 200)$ double-blind, placebo-controlled parallel-group phase 2 study in hospitalised COVID-19 patients requiring supplemental oxygen (OS 5-6) (NCT04402866).

\section{Acknowledgements}

The authors and Theravance Biopharma, Inc., thank the patients and their families for their participation and Kyla Kennedy for clinical operations. Dave Singh, Robert Lord, and Ashley Woodcock are supported by the National Institute for Health Research (NIHR) Manchester Biomedical Research Centre (BRC).

\section{Financial Support}

The study was funded by Theravance Biopharma Ireland Limited. Medical writing and editorial support were provided by Judith M. Phillips, DVM, PhD, of AlphaBioCom, LLC, and funded by Theravance Biopharma US, Inc.

\section{Contributors}

DS, EJM, RL, GDC, AW, BH, and RS contributed to study design and interpretation. DS, MB, VM, and RL enrolled patients, collected data, and contributed to interpretation. DLB and NDP performed pharmacokinetic analyses and contributed to data interpretation. JW and EK contributed to data interpretation. DAL, EYW, and TN performed statistical analyses and contributed to data interpretation. All authors reviewed the manuscript critically for intellectual content and approved the final version for submission. 
medRxiv preprint doi: https://doi.org/10.1101/2021.03.09.21252944; this version posted March 12, 2021. The copyright holder for this preprint (which was not certified by peer review) is the author/funder, who has granted medRxiv a license to display the preprint in perpetuity.

All rights reserved. No reuse allowed without permission.

\section{Declaration of Interests}

DS reports personal fees from Theravance Biopharma during the conduct of the study; and personal fees from AstraZeneca; Boehringer Ingelheim; Chiesi; Cipla; Genentech; GlaxoSmithKline; Glenmark; Menarini; Mundipharma; Novartis; Peptinnovate; Pfizer; Pulmatrix; Theravance Biopharma; and Verona outside this work. MB is an employee of Arensia Exploratory Medicine SRL. VM is an employee of Arensia Exploratory Medicine, LLC. RL reports an independent grant from Vertex Pharmaceuticals for an investigator-initiated study on gastro-oesophageal reflux, honoraria from the Manchester Adult CF Centre for speaking at a conference, and travel awards from the European CF Society and British Thoracic Society. EJM, DLB, NDP, JW, EK, DAL, EYW, TN, and RS are employees of Theravance Biopharma US, Inc., and shareholders of Theravance Biopharma, Inc. GDC is a former employee of Theravance Biopharma US, Inc., and owns shares in Theravance Biopharma, Inc. AW reports fees from Theravance Biopharma, Inc., for consulting on the study design. BH is an employee of Theravance Biopharma UK Limited and shareholder of Theravance Biopharma, Inc.

\section{Data Sharing Statement}

Theravance Biopharma (and its affiliates) will not be sharing individual de-identified participant data or other relevant study documents. 
medRxiv preprint doi: https://doi.org/10.1101/2021.03.09.21252944; this version posted March 12, 2021. The copyright holder for this preprint (which was not certified by peer review) is the author/funder, who has granted medRxiv a license to display the preprint in perpetuity.

All rights reserved. No reuse allowed without permission.

\section{References}

1. McElvaney OJ, McEvoy NL, McElvaney OF, Carroll TP, Murphy MP, Dunlea DM, Ni Choileain O, Clarke J, O'Connor E, Hogan G, Ryan D, Sulaiman I, Gunaratnam C, Branagan P, O'Brien ME, Morgan RK, Costello RW, Hurley K, Walsh S, de Barra E, McNally C, McConkey S, Boland F, Galvin S, Kiernan F, O'Rourke J, Dwyer R, Power M, Geoghegan P, Larkin C, O'Leary RA, Freeman J, Gaffney A, Marsh B, Curley GF, McElvaney NG. Characterization of the Inflammatory Response to Severe COVID-19 Illness. Am J Respir Crit Care Med 2020: 202(6): 812-821.

2. Sims JT, Krishnan V, Chang CY, Engle SM, Casalini G, Rodgers GH, Bivi N, Nickoloff BJ, Konrad RJ, de Bono S, Higgs RE, Benschop RJ, Ottaviani S, Cardoso A, Nirula A, Corbellino M, Stebbing J. Characterization of the cytokine storm reflects hyperinflammatory endothelial dysfunction in COVID-19. J Allergy Clin Immunol 2021: 147(1): 107-111.

3. Wiersinga WJ, Rhodes A, Cheng AC, Peacock SJ, Prescott HC. Pathophysiology, transmission, diagnosis, and treatment of coronavirus disease 2019 (COVID-19): A review. JAMA 2020: 324(8): 782793.

4. World Health Organization. Corticosteroids for COVID-19: Living guidance - 2 September 2020. https://www.who.int/publications/i/item/WHO-2019-nCoV-Corticosteroids-2020.1. Accessed 1 March, 2021.

5. Recovery Collaborative Group, Horby P, Lim WS, Emberson JR, Mafham M, Bell JL, Linsell L, Staplin N, Brightling C, Ustianowski A, Elmahi E, Prudon B, Green C, Felton T, Chadwick D, Rege K, Fegan C, Chappell LC, Faust SN, Jaki T, Jeffery K, Montgomery A, Rowan K, Juszczak E, Baillie JK, Haynes R, Landray MJ. Dexamethasone in hospitalized patients with Covid-19. N Engl J Med 2021: 384(8): 693-704.

6. Kalil AC, Patterson TF, Mehta AK, Tomashek KM, Wolfe CR, Ghazaryan V, Marconi VC, RuizPalacios GM, Hsieh L, Kline S, Tapson V, Iovine NM, Jain MK, Sweeney DA, El Sahly HM, Branche AR, Regalado Pineda J, Lye DC, Sandkovsky U, Luetkemeyer AF, Cohen SH, Finberg RW, Jackson PEH, Taiwo B, Paules CI, Arguinchona H, Goepfert P, Ahuja N, Frank M, Oh MD, Kim ES, Tan SY, 
medRxiv preprint doi: https://doi.org/10.1101/2021.03.09.21252944; this version posted March 12, 2021. The copyright holder for this preprint (which was not certified by peer review) is the author/funder, who has granted medRxiv a license to display the preprint in perpetuity. All rights reserved. No reuse allowed without permission.

Mularski RA, Nielsen H, Ponce PO, Taylor BS, Larson L, Rouphael NG, Saklawi Y, Cantos VD, Ko ER, Engemann JJ, Amin AN, Watanabe M, Billings J, Elie MC, Davey RT, Burgess TH, Ferreira J, Green M, Makowski M, Cardoso A, de Bono S, Bonnett T, Proschan M, Deye GA, Dempsey W, Nayak SU, Dodd LE, Beigel JH, ACTT-2 Study Group Members. Baricitinib plus remdesivir for hospitalized adults with Covid-19. N Engl J Med 2020.

7. Banerjee S, Biehl A, Gadina M, Hasni S, Schwartz DM. JAK-STAT signaling as a target for inflammatory and autoimmune diseases: Current and future prospects. Drugs 2017: 77(5): 521-546.

8. Beigel JH, Tomashek KM, Dodd LE, Mehta AK, Zingman BS, Kalil AC, Hohmann E, Chu HY, Luetkemeyer A, Kline S, Lopez de Castilla D, Finberg RW, Dierberg K, Tapson V, Hsieh L, Patterson TF, Paredes R, Sweeney DA, Short WR, Touloumi G, Lye DC, Ohmagari N, Oh MD, Ruiz-Palacios GM, Benfield T, Fatkenheuer G, Kortepeter MG, Atmar RL, Creech CB, Lundgren J, Babiker AG, Pett S, Neaton JD, Burgess TH, Bonnett T, Green M, Makowski M, Osinusi A, Nayak S, Lane HC, ACTT-1 Study Group Members. Remdesivir for the treatment of Covid-19 - Final report. N Engl J Med 2020: 383(19): 1813-1826.

9. Southworth T, Plumb J, Gupta V, Pearson J, Ramis I, Lehner MD, Miralpeix M, Singh D. Antiinflammatory potential of PI3Kdelta and JAK inhibitors in asthma patients. Respir Res 2016: 17(1): 124. 
Table. Key baseline data and outcomes

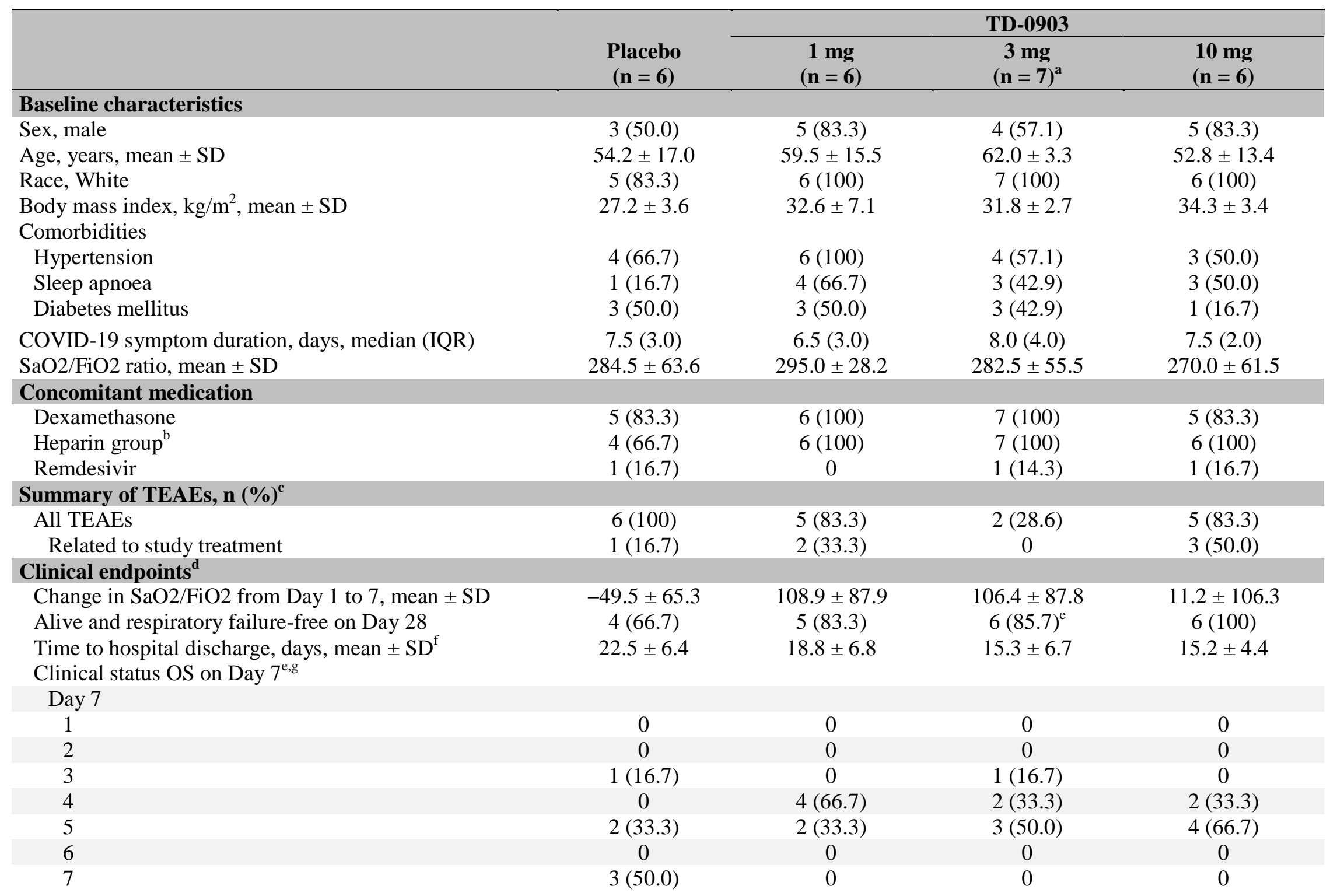




\begin{tabular}{cccc}
8 & 0 & 0 & 0 \\
Day $28^{\mathrm{e}}$ & $3(50.0)$ & $5(83.3)$ & 0 \\
1 & 0 & 0 & 0 \\
2 & 0 & 0 & 0 \\
3 & $1(83.3)$ & 0 & 0 \\
4 & 0 & 0 & 0 \\
5 & 0 & 0 & 0 \\
6 & 0 & 0 & 0 \\
7 & 0 & 0 & 0 \\
8 & $2(33.3)$ & 0 & 0 \\
\hline
\end{tabular}

Data are shown as n (\%) unless otherwise specified.

${ }^{a}$ One patient discontinued the study due to subsequent negative PCR test for SARS-CoV-2 and was replaced but included in analyses as available data permitted.

${ }^{\mathrm{b}}$ Includes heparins, enoxaparin, bemiparin, and nadroparin.

${ }^{c}$ Including patients who received $\geq 1$ dose of study drug analysed as treated.

${ }^{\mathrm{d}}$ Including all randomised patients analysed as randomised (intent-to-treat population).

${ }^{\mathrm{e}}$ The patient who discontinued the study due to negative PCR test for SARS-CoV-2 was known to be alive but with unknown clinical status at Day 28. Thus, this patient was not counted as alive and respiratory failure-free and was not included in analyses of OS on Days 7 and 28.

${ }^{\mathrm{f}}$ For patients who died or were still hospitalised on Day 28, a time to discharge of 28 days was assigned.

${ }^{g} 8$-point OS: 1, not hospitalised, no limitations on activities; 2 , not hospitalised, but with limitation on activities and/or requiring home oxygen; 3 , hospitalised, not requiring supplemental oxygen, and no longer requiring ongoing medical care (including hospitalisation for infection control); 4 , hospitalised, not requiring supplemental oxygen but requiring ongoing medical care (whether related or not to COVID-19); 5, hospitalised,

requiring supplemental oxygen; 6 , hospitalised, on noninvasive ventilation or high-flow oxygen devices; 7 , hospitalised, on invasive mechanical ventilation or extracorporeal membrane oxygenation; 8 , death.

IQR, interquartile range; OS, ordinal scale; $\mathrm{SaO} 2 / \mathrm{FiO} 2$, ratio of oxygen saturation by pulse oximetry to fraction of inspired oxygen; SARS-CoV-2, severe acute respiratory syndrome coronavirus 2; SD, standard deviation; TEAE, treatment-emergent adverse event. 